\title{
Quantifying carbon in dead and living trees; a case study in young beech and spruce stand over 9 years
}

\author{
Vladimír Šebeň ${ }^{1 *}$, Bohdan Konôpka ${ }^{1,2}$, Jozef Pajtík ${ }^{1}$ \\ ${ }^{1}$ National Forest Centre, Forest Research Institute Zvolen, T. G. Masaryka 2175/22, SK - 96092 Zvolen, Slovak Republic \\ ${ }^{2}$ Czech University of Life Sciences Prague, Faculty of Forestry and Wood Sciences, Kamýcká 129, CZ - 16521 Praha 6 - Suchdol, \\ Czech Republic
}

\begin{abstract}
In Slovakia, the contribution of young stands to the total forest area has been increasing in the last decade. However, scientific attention to these stands was previously very sparse and they were usually not included in local and country carbon stock estimates. Therefore, we focused on the calculation of tree biomass and necromass in young beech and spruce stands as well as on their development during the period of nine years (aged from 4 to 12 years). For the calculation, we implemented allometric equations using tree diameter and height as independent variables. The results showed very dynamic changes in biomass (carbon) stock. Specifically, tree biomass increased in the period of 9 years from about $2,000 \mathrm{~g}$ to $15,000 \mathrm{~g}$ (i.e. cca 1,000 to 7,500 $\mathrm{g}$ of carbon) per $\mathrm{m}^{2}$ in beech, and from 4,500 to $12,000 \mathrm{~g}$ (cca 2,300 to 6,000 $\mathrm{g}$ of carbon) per $\mathrm{m}^{2}$ in the spruce stand. At the same time, the amount of biomass (fixed carbon) was only slightly larger than the accumulated quantity of necromass (carbon loss from living trees). It means that a large portion of carbon was allocated to necromass. We found that not only the foliage fall but also the mass of dead trees, a result of intensive competition, was an important path of carbon flux to necromass. The results proved that although young forests fix much less carbon in their biomass than old stands, they can represent large carbon flux via annual increment of necromass. This indicates that young stands should not be omitted in forest carbon balance estimates of the country.
\end{abstract}

Key words: young trees; Fagus sylvatica; Norway spruce; stand development; carbon stock, tree components

Editor: Jan Kašpar

\section{Introduction}

European beech (Fagus sylvatica) and Norway spruce (Picea abies) are the most important species not only in Slovakia but also in the essential part of other European countries. Their importance is linked to their high contribution to species composition of forests, their high commercial value, but certainly also to their large accumulation of carbon.

As for the Slovak Republic, the Green Report (Ministry of Land Management and Rural Development of SR, 2016) shows that in the recent tree species composition of the country, beech made $31 \%$ and spruce $26 \%$. Both species are typical with their good regeneration and high capacity in inter-species competition on the territory of Slovakia. Thus, in young stages (categorised as first age class, i.e. 0 - 10 year-old) beech contributed to species composition with as much as $35 \%$ and spruce with $25 \%$ prevailingly as a result of natural regeneration (Konôpka J. et al. 2016). It means that these species will form a considerable part of the Slovak forests also in the next many decades. At the same time, a current phenomenon of the Slovak forestry is an over-standard proportion of young forests stands in comparison to the normal forest age class distribution. Specifically, forest stands with age up to 10 years cover 200 thousand ha, which is the largest area from all age classes (Ministry of Land Management and Rural Development of SR, 2016). This is mainly caused by an extraordinary high occurrence of disturbances since the year 2004 (Kunca et al. 2015; Nikolov et al. 2014).

In fact, most previous research activities in Slovakia but also in many other developed countries, including a variety of aspects, were focused on old forest stands rather than on young growth stages. That could be probably linked to a more economical than an ecological vision in a part of scientific community, or specifically in the field of production ecology, perhaps also to an underestimation of the significance of young forests for carbon sequestration and cycling. Thus, for instance biomass 
models were often constructed for large trees but small trees were traditionally omitted (e.g. Wirth et al. 2004).

As for tree biomass, eventually carbon pool in trees, it is undisputable that much larger amounts are in old forests than in young growths (e.g. Helmisaari et al. 2002). On the other hand, young forests are much more dynamic (especially in terms of inter-annual changes in biomass stock) and they have different biomass allocation in comparison with old forest stands (Konôpka et al. 2017). Moreover, young forests have much higher mortality rates than old forests that are related especially to high competition for light in the initial stages of growth (Larson et al. 2015). Although most of the perished trees (obviously suppressed) in young stands are smaller than those in the main canopy layer, they can make a large portion of carbon loss (flux). This carbon flux is considerable especially in naturally regenerated stands with typically high tree density.

Since beech is a deciduous and spruce an evergreen tree species, certain differences can be expected in their biomass allocation and also in their carbon regimes. Previously we showed much higher contribution of foliage to total biomass in spruce young stands than in beech young stands (Pajtík et al. 2013). On the other hand, the contributions of their foliage to net primary productivity were very similar. At the same time, we found much higher mortality rate in spruce than in beech young stands that was explained not only by different light conditions under the canopy but also by contrasting ecological properties of these species. Although our previous study (Konôpka et al. 2011; Pajtík et al. 2013) showed the results on biomass allocation and net primary productivity in developing young beech and spruce stands, we did not estimate either the amount of carbon sequestrated in tree biomass or the carbon flux realised via aboveground litter fall from living trees and body of died trees.

In fact, our literature review indicated that this kind of carbon quantification in young stands is totally missing in any other studies conducted all over the world. Thus, this paper focused on the estimation of biomass (living trees) and necromass (all components of dead trees and foliage litter fall from living trees) in young stands of beech and spruce with special attention to their carbon amount. Moreover, we aimed at quantification of carbon fixed and "lost" (transferred) from trees in the form of foliage fall and dead trees in these two stands over the nine-year period. Although the stands were of the same age, they grew under the different site conditions, due to which their contrasting properties (carbon pool and flux) were intended to be interpreted with a certain level of caution.

\section{Material and methods}

\subsection{Research plots}

We used a part of data originating from the empirical dataset of 12 research sites situated in forests of the Central and Northern Slovakia. The original dataset was rep- resented by 6 pure spruce and 6 pure beech stands. The research plots were established for long-term monitoring of development young forests including the assessment of tree growth, competition and mortality. At the beginning of our research, the stands had a different mean age; the youngest stand was 4 years old while the oldest one was 14 years old. Each year, from 2008 to 2016 we measured height and diameter of trees in the young forest stands. Since the main intention of this paper was to record the development of a very initial growth phase, we selected two youngest stands from the dataset: one was the youngest beech stand and the other one was the youngest spruce stand. The chosen beech stand is situated in a locality named the Pustý Hrad Hill (Fig. 1) and the spruce stand was in the locality named Zákopčie.

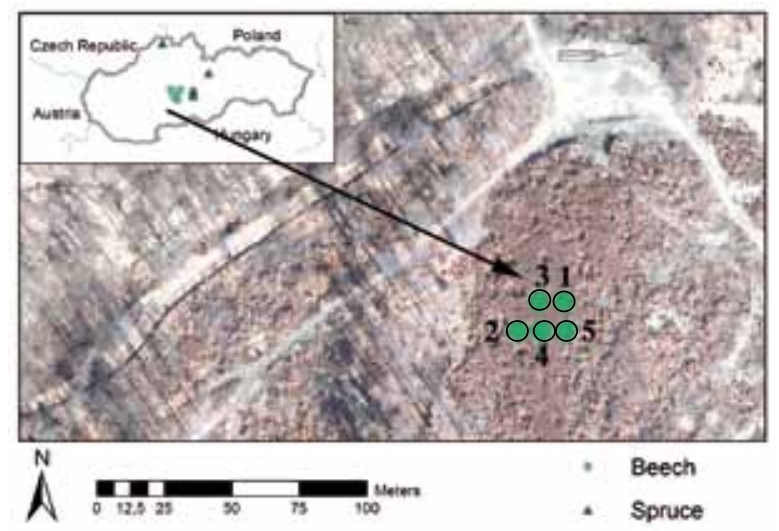

Fig. 1. Location of sites for long-term monitoring of development of young beech and spruce forest stands in Slovakia; a detailed view shows the locality of Pustý Hrad Hill with 5 subplots established in the homogenous beech stand.

The main criterion for the stand selection was that the stand was composed of single tree species, i.e. it was either pure beech or pure spruce stand without admixture of other tree species, originating exclusively from natural regeneration. Five circular suplots were established in every stand. A radius of subplots was variable, specifically between $0.5-2 \mathrm{~m}$ that depended on stand density aiming at a minimum number of trees over 30 individuals. The distance between the borders of individual subplots was at least $3 \mathrm{~m}$ to ensure their independence. In the locality of Pustý hrad, four subplots with a radius of $0.5 \mathrm{~m}$ and one subplot with a radius $0.6 \mathrm{~m}$ were established, while in the Zákopčie locality, five subplots with a radius of $0.8 \mathrm{~m}$ were set up.

The Pustý Hrad Hill is located near the town of Zvolen, in the volcanic mountain range of Javorie. The forests are managed by the Zvolen Town Forest Enterprise (urban forests). The coordinates of the site are $48.5521^{\circ}$ North latitude and $19.1253^{\circ}$ East longitude. The elevation is between $460-470 \mathrm{~m}$, the exposure is east. The site represents the oak-beech forest vegetation zone, the primary vegetation is represented by Querceto-Fagetum forest type group (oak-beech forests). The bedrock is 
made of andesite, the soils are skeletic-mesotrophic cambisols. The forests belong to commercial-purpose forests. In the monitored stands, no thinning cuts have been performed so far.

The locality Zákopčie is located near the town of Čadca, Northern Slovakia, in the Kysuce Beskids Mountains. The territory is owned and managed by the State Forest Enterprise (state forests). The coordinates of the site are $49.4193^{\circ}$ North latitude and $18.7328^{\circ}$ East longitude. The elevation is between $520-530 \mathrm{~m}$, the exposure is north. The site represents spruce-beech-fir mountain forests; the primary vegetation is represented by FagetoAbietum (nutrient rich beech-fir stands). The territory belongs to the flysch, the bedrock is made of sand-stone, and the soils are skeletic mesotrophic cambisoils. The forest belongs to commercial-purpose forests, and in the monitored spruce stands no thinning cut has been performed so far.

\subsection{Field measurements}

The radius of each subplot was chosen to capture at least 30 trees within the plot area. All individuals were marked with a metal label with a code in 2008 to ensure clear identification of all trees in repetitive measurements. Every year, the life status (living or dead) of each individual was evaluated after the end of the growing period. On living trees, the stem base diameter (SBD) was measured in two perpendicular directions with a digital caliper with an accuracy of $0.1 \mathrm{~mm}$. Moreover, tree heights were measured using the height-patch with an accuracy to the nearest centimeter (up to height $3.0 \mathrm{~m}$ ) or to the nearest $10 \mathrm{~cm}$ (over $3.0 \mathrm{~m}$ ). In the case when the individual tree height exceeded $1.3 \mathrm{~m}$, diameter at breast height (DBH) was measured to the nearest 0.1 millimeter in two perpendicular diameters. Between 2008 and 2016 nine repeated measurements were performed.

At the beginning of the measurements the average (mean) age rounded to one year was assigned to each stand. The age was assessed by combining the information from the Forest Management Plans and ring analyses of discs (10 pieces) sampled from the stem bases of the trees selected close to the research subplots.

The sites "Pustý Hrad" (beech) and "Zákopčie" (spruce) were selected as youngest and thus with the highest tree density. In the beech stands the smallest number of the measured living trees on the subplots was 29 , and the highest number was 68 (average of 43 trees), while in the spruce stands we recorded minimum and maximum of 43 and 75 living trees, respectively (average 58 trees). In both cases, the estimated mean age at the beginning of the measurements in 2009 was 4 years. At the beginning of the measurements we recorded in total 215 trees or 290 trees on all subplots in the beech and spruce stands, respectively. Out of them, 57 beech trees and 48 spruce trees survived 9 years until the last measurement.

\subsection{Statistical calculations}

The measured values from 9 annual repeated measurements (mortality, height, SBD, and DBH) were edited and the database was debugged. The data were processed in Ms Excel and Ms Access software (Microsoft Office). After the basic data processing, an algorithm for the calculation of average values, standard deviation and the variability of variables (diameter, height, and number of individuals) at the subplot and whole site levels was prepared. The mortality rates were calculated by two methods: based on the tree number and on the basal area (derived from SBD). While the method involving the tree number was calculated for each year as a proportion of the number of dead trees to the initial number of trees (i.e. the same basis), the method linked to the basal area was based on a different principle. Specifically, this method was calculated as a proportion of the basal area of the trees that died in the current year to the basal area of the surviving individuals (i.e. moving value which changes over time as a result of both stem growth and tree mortality).

\subsection{Biomass calculation}

To calculate the biomass of the whole trees as well as the biomass of individual tree components no samples were taken from the plots, but our previously constructed allometric equations were applied (according to papers of Pajtík et al. 2008; Konôpka et al. 2011; Pajtík et al. 2011; see also Appendix 1 and 2). In the case of dead trees and foliage fall, we used the same calculation method as for the living trees to derive the necromass. We distinguished the foliage fall from the living trees and the dead foliage from the trees that died in a particular year. Foliage fall for beech was derived as an amount of annual living foliage, while the foliage fall for spruce was derived as one fifth of the foliage living in a particular year. The SBD diameter and tree height were used as independent variables in the equations. Thus, the biomass (necromass) for the following tree components: stem (inside bark), branches, leaves (needles) and roots was calculated. Subsequently we calculated the biomass and the newly created necromass (i.e. annual input to necromass) for each year and each subplot, converted the values to area unit, and averaged for the whole site. Note that the results on tree necromass presented in the paper did not represent its total amount starting from the beginning of the stand existence. Actually, our outputs are related to the annual foliage fall and the annual necromass increment in each year of the observations. Besides that, we calculated the cumulated values (during the period of 9 years) for these two variables.

Afterwards, carbon quantity can be was estimated as $50 \%$ of tree biomass or necromass (see for instance Thomas \& Martin 2012). The presented results of the stands used mean values and sampling errors calculated at $68 \%$ confidence interval. 


\section{Results}

The comparison of the relationship between SBD and tree height at the beginning and the end of the observation period showed aincrease of the variance over time. The ranges of beech and spruce tree heights were comparable at both sites even after 9 years. However, at the same tree height the diameter range of spruce trees is larger than the range of beech trees at either of the two surveys (i.e., in 4 years and in 12 years; Fig. 2).

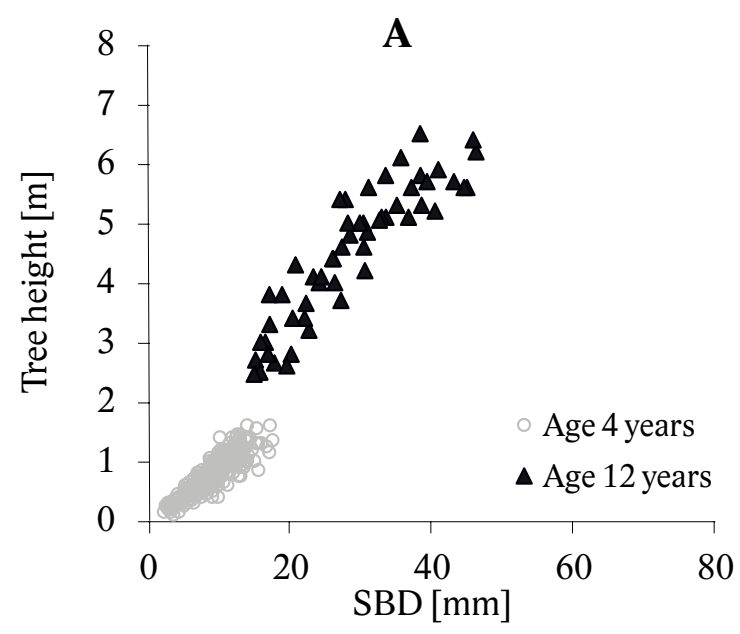

ity. We experienced a gradual increase of mortality until the age of about 9 years. After that, there was a slight decrease in the mortality rate in both beech and spruce stands. From the stand age of about 10 years, the mortality rate based on the basal area started to grow again. However, the differences in the mortality rate between the beech and spruce stands were not large.

The biomass of each tree component as well as the total tree aboveground biomass of beech was gradually increasing between $4^{\text {th }}$ and $12^{\text {th }}$ year of the stand (Fig.

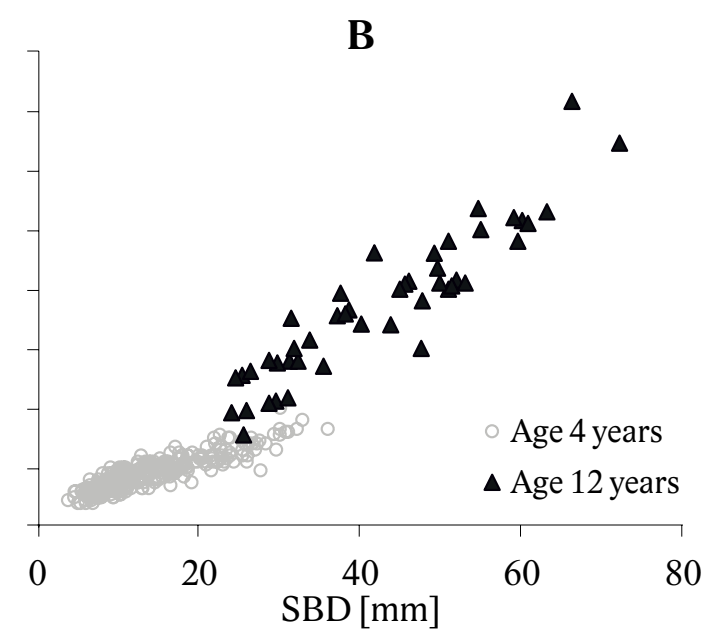

Fig. 2. Confrontation of changes in relationships between SBD and tree height after 9 years in young beech stand (A) and spruce stand (B).

During the 9 years, a severe tree number reduction caused by competition occurred in both young stands (no thinning was performed there). At the age of about 12 years, cumulative stand mortality in the beech stand reached approximately $70 \%$ of the number of individuals in the 4-year-old stand, while the cumulative mortality in the spruce stand (Fig. 3) was higher, up to $80 \%$ of the initial number of trees.

The mortality rate calculated from stem base basal area has a different temporal development, because the basal area changed in time due to the growth and mortal-
4). In contrast to beech, in the spruce stand we observed the slowdown of biomass increment (or even its slight decrease) at the age of 11 years (Fig. 5), which was linked to the increased mortality.

While the young beech forest at the age of 12 years reached an average total biomass (aboveground and underground) of about $15 \mathrm{~kg} \mathrm{per}^{2}$, the spruce biomass

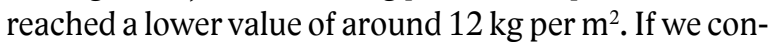
sider carbon content in biomass of $50 \%$, these biomass amounts represented the carbon stock of about $7.5 \mathrm{~kg}$ and $6 \mathrm{~kg}$ per $\mathrm{m}^{2}$ in the beech and spruce stand, respectively.
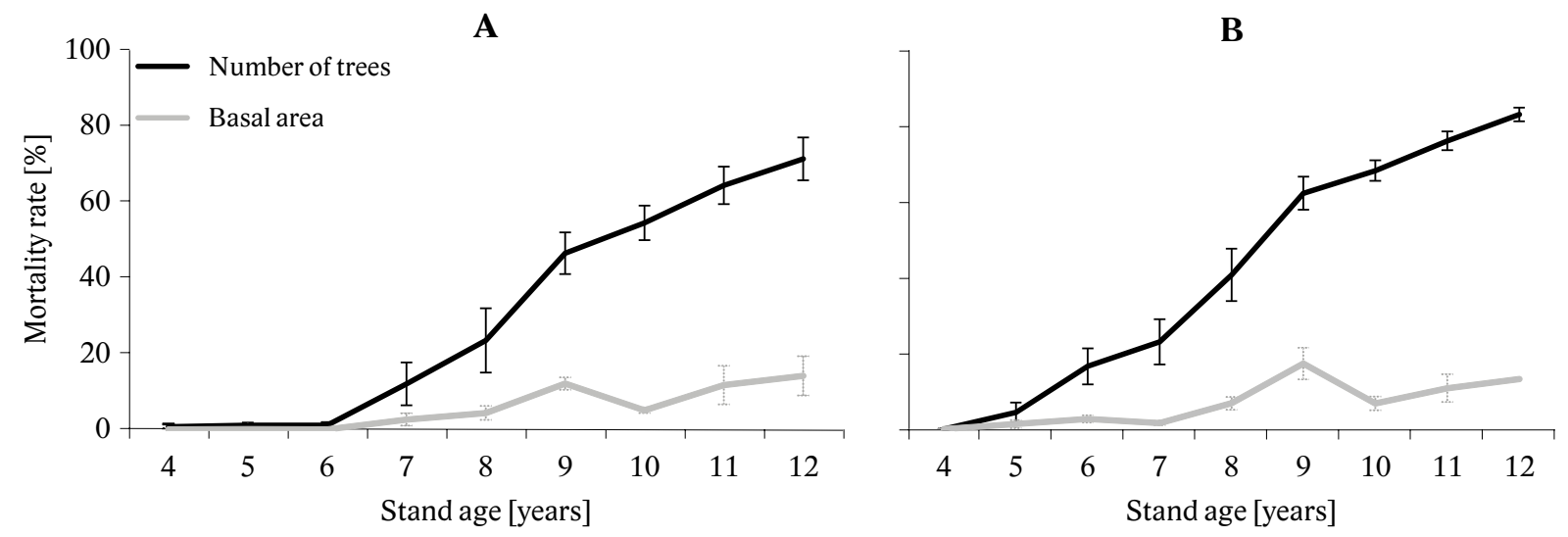

Fig. 3. Development of beech mortality rate (A) and spruce stand mortality rate (B). 

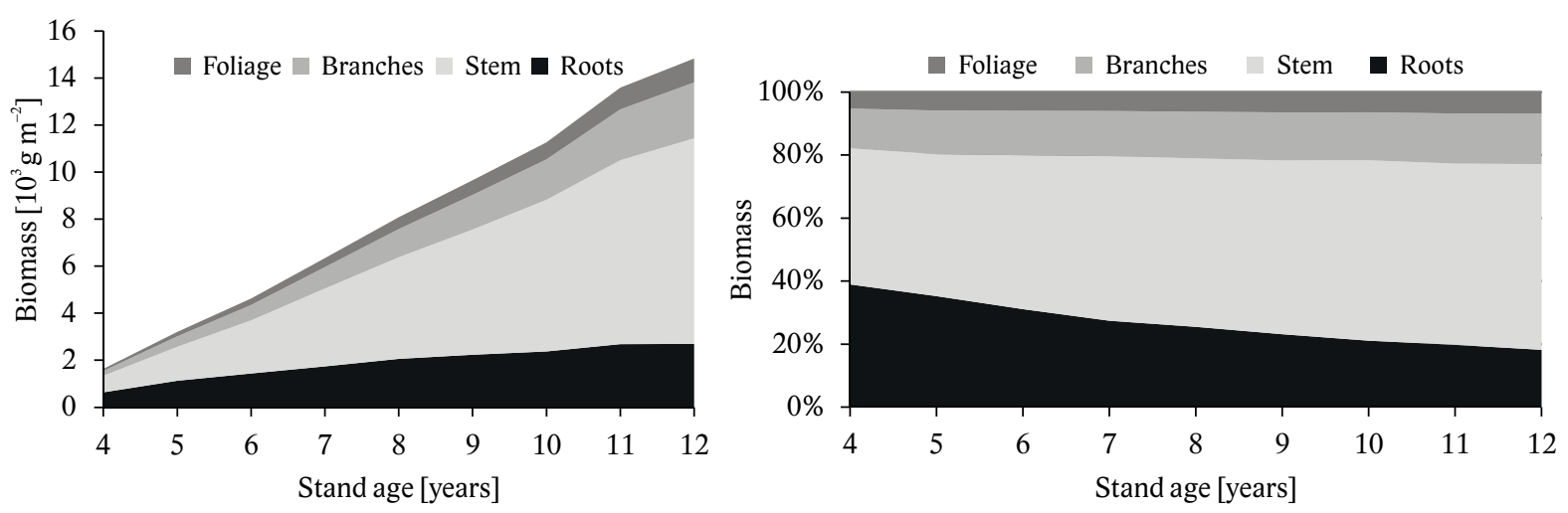

Fig. 4. Biomass development during the period of 9 years in the young beech stand (absolute and relative comparison).
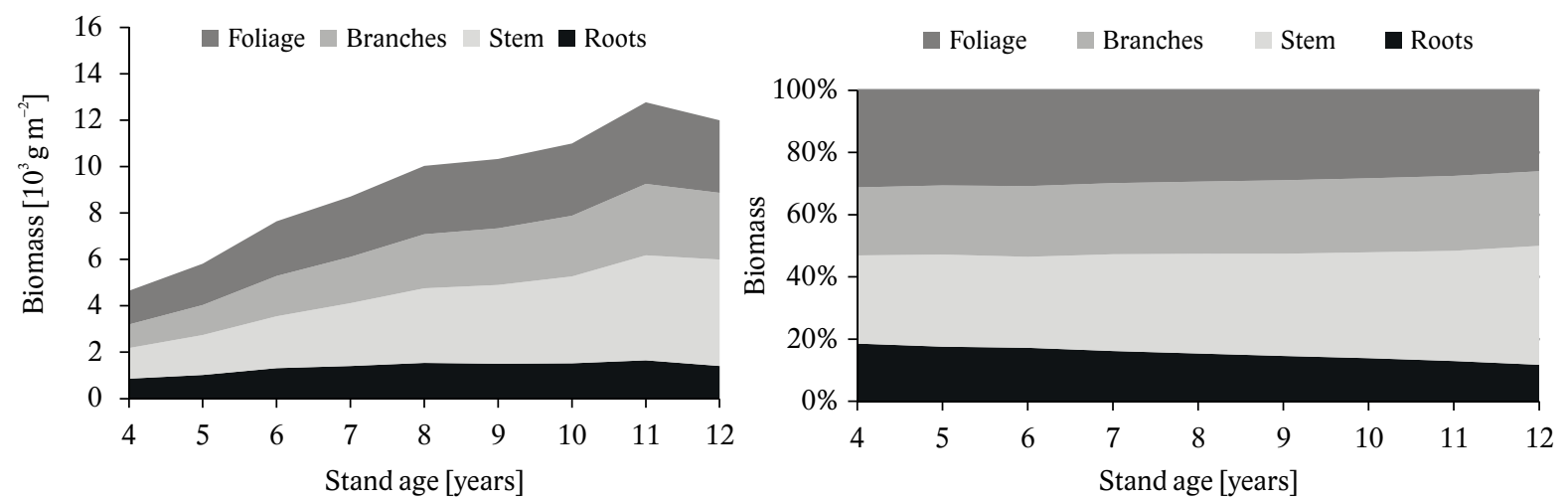

Fig. 5. Biomass development during the period of 9 years in the young spruce stand (absolute and relative comparison).

As for the proportions of the biomass in individual tree components, we identified the differences between the species as well as with the stand development. While beech during 9 years changed the proportion of roots from about $35 \%$ to $20 \%$, in the spruce stand the root proportion declined from about $20 \%$ to almost $10 \%$. The largest contribution to the total biomass of beech was made by the stem. Its share rose from about $40 \%$ to $50 \%$. In the case of spruce, the proportion of the stem biomass from the total biomass was significantly lower, but showed asimilar $10 \%$ increase (its share was $30 \%$ and $40 \%$ in the age of 4 and 12 years, respectively). Needles contributed to the total spruce biomass by $30 \%$ (in the 4-year-old stad), while its proportion only slightly decreased to about $25 \%$ over the 9-year period (12-year-old). The beech leaves accounted for about $5 \%$ of the whole-tree biomass at the age of 4 years, which continuously increased to about $7 \%$ at the age of 12 years.

The annual input into necromass (i.e. annual foliage fall and annual tree mortality) in the stands is presented in Figure 6 (beech stand) and in Figure 7 (spruce stand). In the first three years of the observations, we recorded only a single component of the necromass in the beech stand aged under 6 years, namely fallen leaves from the living trees. In the following years, we also observed mortality of individual trees particularly due to the competition processes. From the age of 9 years, the contribution of tree mortality to the annual input into necromass became greater (of around $40 \%$ ). However, the foliage fall dominated in the annual input to necromass, since it formed more than $50 \%$ of the total new necromass. The situation was significantly different in the spruce stand. Although in the spruce stand the needle fall from the surviving individuals also dominated in the annual input into necromass, its proportion was significantly lower than in the beech stand. Moreover, its dominance lasted only until the age of 8 years, after which the woody parts of the perished individuals started to prevail in the newly created necromass.

The development of the living and dead tree parts of the beech and spruce forests are given in Table 1, 2, 3, and 4 . The mean stand heights of both tree species in the young stands were similar, but during the monitoring period beech height grew a little faster than spruce height (mainly from the age of 7 years). On the contrary, spruce reached a significantly higher mean diameter (SBD) than beech. Tree mortality in the spruce stand was much higher than in the beech stand. 

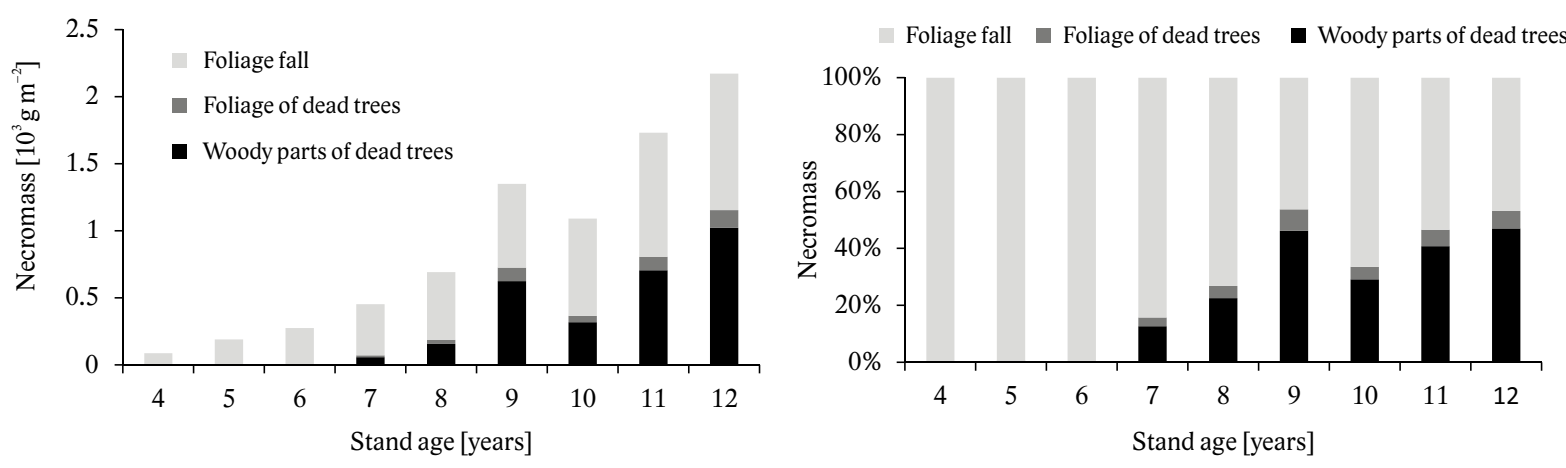

Fig. 6. Development of annual input to necromass during 9-year-development in young beech stand (absolute values in the left graph, relative values in the right graph).
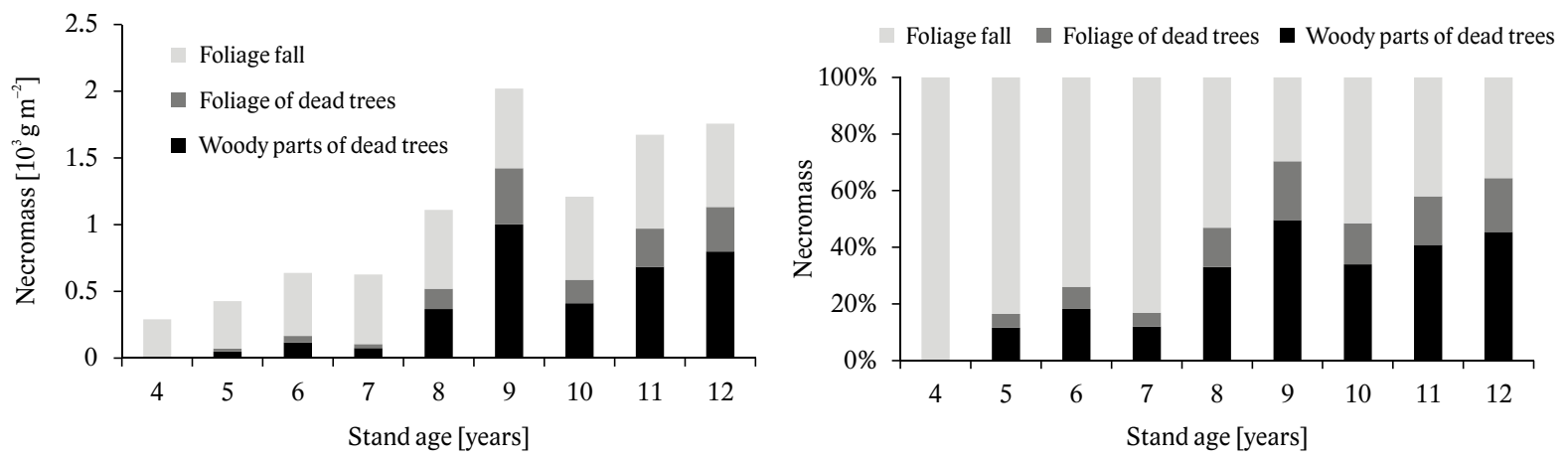

Fig. 7. Development of annual input to necromass during 9-year development in young spruce stand (absolute values in the left graph, relative values in the right graph).

Table 1. Development of stand characteristics of living trees in the young beech stand (mean value $\pm 68 \%$ standard error).

\begin{tabular}{|c|c|c|c|c|c|c|c|c|c|}
\hline \multirow{2}{*}{ Stand characteristics } & \multicolumn{9}{|c|}{ Stand age [years] } \\
\hline & 4 & 5 & 6 & 7 & 8 & 9 & 10 & 11 & 12 \\
\hline Height [m] & $0.9 \pm 0.1$ & $1.2 \pm 0.1$ & $1.5 \pm 0.1$ & $2.0 \pm 0.1$ & $2.4 \pm 0.2$ & $3.0 \pm 0.2$ & $3.5 \pm 0.3$ & $4.1 \pm 0.2$ & $4.8 \pm 0.2$ \\
\hline $\mathrm{SBD}[\mathrm{mm}]$ & $10.1 \pm 0.8$ & $12.8 \pm 1.1$ & $14.1 \pm 1.3$ & $16.0 \pm 1.2$ & $18.3 \pm 1.1$ & $21.9 \pm 1.2$ & $24.2 \pm 1.5$ & $28.2 \pm 1.9$ & $31.6 \pm 2.0$ \\
\hline Stand density [ $\mathrm{N}$ per $\left.\mathrm{m}^{2}\right]$ & $52 \pm 11$ & $52 \pm 11$ & $52 \pm 11$ & $44 \pm 7$ & $36 \pm 4$ & $26 \pm 3$ & $22 \pm 3$ & $17 \pm 3$ & $14 \pm 3$ \\
\hline Basal area* $\left[\mathrm{cm}^{2} \mathrm{~m}^{-2}\right]$ & $37 \pm 2$ & $59 \pm 4$ & $72 \pm 5$ & $83 \pm 7$ & $93 \pm 8$ & $95 \pm 10$ & $98 \pm 10$ & $103 \pm 13$ & $101 \pm 17$ \\
\hline
\end{tabular}

Note: *Basal area at stem base (calculated from stem base diameter SBD).

Table 2. Development of stand characteristics of trees that died in the particular year in the young beech stand (mean value \pm $68 \%$ standard error).

\begin{tabular}{|c|c|c|c|c|c|c|c|c|c|}
\hline \multirow{2}{*}{ Stand characteristics } & \multicolumn{9}{|c|}{ Stand age [years] } \\
\hline & 4 & 5 & 6 & 7 & 8 & 9 & 10 & 11 & 12 \\
\hline Height [m] & 0 & $0.3 \pm$ & 0 & $0.5 \pm 0.0$ & $0.8 \pm 0.1$ & $1.4 \pm 0.2$ & $1.8 \pm 0.2$ & $2.3 \pm 0.2$ & $2.7 \pm 0.2$ \\
\hline $\mathrm{SBD}[\mathrm{mm}]$ & 0 & $5.1 \pm$ & 0 & $7.1 \pm 1.0$ & $8.5 \pm 0.5$ & $11.9 \pm 1.3$ & $13.3 \pm 1.0$ & $15.7 \pm 0.9$ & $21.2 \pm 2.3$ \\
\hline Stand density $\left[\mathrm{N}\right.$ per $\left.\mathrm{m}^{2}\right]$ & $0 \pm 1$ & $0 \pm 1$ & \pm 1 & $8 \pm 6$ & $7 \pm 9$ & $11 \pm 5$ & $4 \pm 5$ & $5 \pm 5$ & $4 \pm 6$ \\
\hline Basal area* $\left[\mathrm{cm}^{2} \mathrm{~m}^{-2}\right]$ & \pm 0 & $0 \pm 0$ & \pm 0 & $2 \pm 2$ & $4 \pm 2$ & $11 \pm 2$ & $5 \pm 1$ & $10 \pm 5$ & $11 \pm 5$ \\
\hline
\end{tabular}

Note: *Basal area at stem base.

Table 3. Development of stand characteristics of living trees in the young spruce stand (mean value $\pm 68 \%$ standard error).

\begin{tabular}{|c|c|c|c|c|c|c|c|c|c|}
\hline \multirow{2}{*}{ Stand characteristics } & \multicolumn{9}{|c|}{ Stand age (years) } \\
\hline & 4 & 5 & 6 & 7 & 8 & 9 & 10 & 11 & 12 \\
\hline Height [m] & $1.0 \pm 0.1$ & $1.2 \pm 0.1$ & $1.4 \pm 0.1$ & $1.6 \pm 0.2$ & $2.0 \pm 0.2$ & $2.4 \pm 0.2$ & $2.7 \pm 0.2$ & $3.4 \pm 0.2$ & $4.2 \pm 0.1$ \\
\hline $\mathrm{SBD}[\mathrm{mm}]$ & $15.7 \pm 0.7$ & $17.5 \pm 0.9$ & $21.0 \pm 1.4$ & $22.8 \pm 1.7$ & $27.2 \pm 1.9$ & $33.4 \pm 2.0$ & $36.1 \pm 1.5$ & $43.0 \pm 1.6$ & $47.2 \pm 0.7$ \\
\hline Stand density $\left[\mathrm{N}\right.$ per $\left.\mathrm{m}^{2}\right]$ & $29 \pm 3$ & $28 \pm 3$ & $24 \pm 3$ & $23 \pm 4$ & $18 \pm 4$ & $11 \pm 2$ & $9 \pm 1$ & $7 \pm 1$ & $5 \pm 0$ \\
\hline Basal area* $\left[\mathrm{cm}^{2} \mathrm{~m}^{-2}\right]$ & $55 \pm 3$ & $64 \pm 3$ & $80 \pm 3$ & $87 \pm 3$ & $94 \pm 4$ & $90 \pm 3$ & $91 \pm 5$ & $97 \pm 8$ & $84 \pm 8$ \\
\hline
\end{tabular}

Note: *Basal area at stem base.

In fact, comparison between live and dead tree mass, eventually proportions of carbon allocation into biomass and necromass, in the developing young stands might be done in a variety of ways. In our case, theoretical comparison between biomass stock of live trees recorded in the last year of measurements against necromass accumulated over 9 years (i.e. total carbon transferred from biomass to necromass) was used. At the same time, we did not consider processes of necromass decomposition (annual decreases) in the stands. 
Table 4. Development of stand characteristics of trees that died in the particular year in the young spruce stand (mean value \pm $68 \%$ standard error).

\begin{tabular}{|c|c|c|c|c|c|c|c|c|c|}
\hline \multirow{2}{*}{ Stand characteristics } & \multicolumn{9}{|c|}{ Stand age [years] } \\
\hline & 4 & 5 & 6 & 7 & 8 & 9 & 10 & 11 & 12 \\
\hline Height [m] & 0 & $0.6 \pm 0.1$ & $0.6 \pm 0.1$ & $0.8 \pm 0.0$ & $1.0 \pm 0.1$ & $1.3 \pm 0.2$ & $1.6 \pm 0.2$ & $1.7 \pm 0.1$ & $2.0 \pm 0.2$ \\
\hline $\mathrm{SBD}[\mathrm{mm}]$ & 0 & $7.9 \pm 1.0$ & $8.6 \pm 0.8$ & $9.9 \pm 0.9$ & $12.6 \pm 1.8$ & $17.9 \pm 1.9$ & $23.1 \pm 3.1$ & $23.5 \pm 1.9$ & $28.6 \pm 3.2$ \\
\hline Stand density $\left[\mathrm{N}\right.$ per $\left.\mathrm{m}^{2}\right]$ & 0 & $1 \pm 3$ & $3 \pm 5$ & $2 \pm 6$ & $5 \pm 7$ & $7 \pm 4$ & $2 \pm 3$ & $2 \pm 2$ & $2 \pm 2$ \\
\hline Basal area* $\left[\mathrm{cm}^{2} \mathrm{~m}^{-2}\right]$ & 0 & $1 \pm 1$ & $2 \pm 1$ & $1 \pm 1$ & $6 \pm 2$ & $15 \pm 4$ & $6 \pm 2$ & $10 \pm 4$ & $11 \pm 1$ \\
\hline
\end{tabular}

Note: *Basal area at stem base.

The final balance of biomass and necromass quantities in both stands showed a relatively high proportion of the built necromass after 9 years in comparison with the biomass stock of living trees in the last year (Table 5 ). The total quantity of necromass (foliage fall plus whole body of dead trees) produced over the nine years of observations was about 8,000 $\mathrm{g}$ and $9,750 \mathrm{~g} \mathrm{per}^{2}$ in the beech and spruce stand, respectively. It represented $57 \%$ and $87 \%$ of the biomass of living trees in the last year of observations for beech and spruce, respectively $\left(14,160 \mathrm{~g} \mathrm{per}^{2}\right.$ in beech and $11,260 \mathrm{~g} \mathrm{per}^{2}$ in spruce stand). In the beech stand, as much as $59 \%$ of the total necromass production originated from the foliage fall. However, in the spruce stand the contribution of foliage fall to the total aboveground necromass production was significantly lower (49\%). If we switch our interpretation from the dry tree matter to carbon amount, we can report that the 14-year-old stand fixed about 7,000 $\mathrm{g}$ and $5,600 \mathrm{~g}$ of carbon per $\mathrm{m}^{2}$ in the tree biomass of beech and spruce, respectively. Moreover, during the nine years of observations, the carbon transfer from the tree biomass to necromass (including both tree mortality and foliage fall) was approximately $4,000 \mathrm{~g}$ and $4,900 \mathrm{~g} \mathrm{per}^{2}$ in the beech and spruce stand, respectively.

\section{Discussion and conclusion}

At the beginning of this section we would like to point out again that the beech and spruce stands were of the same ages but grew under the different site conditions. Specifically, the beech stand was on a warmer and drier location, southern part of Central Slovakia and eastern exposition - on a more nutrient rich soil, while the spruce stand was situated in northern Slovakia, at north-oriented exposition on acidic soil. Thus, although the contrasting situations in their developments are commented here, the inter-specific differences might indicate certain general patterns but should not be taken as generally applicable.
Actually, the results showed very dynamic changes in the biomass (carbon) stock. Specifically, in the period of 9 years the biomass of beech increased from about 2,000 $\mathrm{g}$ to $14,000 \mathrm{~g}$ (i.e. cca 1,000 to $7,000 \mathrm{~g}$ of carbon) per $\mathrm{m}^{2}$, and from 4,600 to $12,000 \mathrm{~g}$ (cca 2,300 to $6,000 \mathrm{~g}$ of carbon) per $\mathrm{m}^{2}$ in the spruce young stand. Hence, the biomass (carbon) increased more in the beech than in the spruce stand that might be related not only to the inter-specific contrasts in the growth rates but also to the differences in their stand and site properties. In fact, also our previous study (Pajtík et al. 2013) conducted in young beech and spruce stands grown at the identical sites indicated larger net primary productivity of beech than spruce. The difference occurred mainly due to the higher amount of assimilates allocated intobeech stems. Similarly, in our present work, stem biomass production of beech was nearly double the production in spruce. We can assume a stem to be a tree component with the longest turnover that would be a positive phenomenon in terms of carbon sequestration. On the other hand, the disadvantage of beech in carbon sequestration is its annual foliage rotation in comparison with spruce (i.e. deciduous versus evergreen species). Thus, while the standing stock of foliage in the spruce stand was approx. triple of that in the beech stand, the amount of foliage fall was very similar in both stands.

The results from our young stands showed, that not only foliage fall but also mass of dead trees (woody parts and foliage) are important paths of carbon flux. We could see that the contribution of the foliage fall to necromass was similar in both stands, but they had a different proportion of dead trees (more in spruce than in beech). Another question is further carbon "fate", i.e. decomposition rate and subsequently carbon emission from dead woody parts (expecting specific behavior for those in the soil, i.e. roots and on the ground, i.e. stem and branches) and shed foliage. For instance, Konôpka (2017) showed that that aboveground litter in young beech stand (necromass mainly composed of leaves)

Table 5. Tree biomass - status in the last year of observation, and necromass - expressed as cumulative amount during 9-yearobservation in the young stands of beech and spruce.

\begin{tabular}{|c|c|c|c|c|c|c|c|}
\hline \multirow{2}{*}{ Stand } & \multirow{2}{*}{$\begin{array}{l}\text { Expression of quantity } \\
\text { [unit] }\end{array}$} & \multicolumn{2}{|c|}{ Live trees - biomass } & \multirow{2}{*}{$\frac{\text { Live trees - necromass }}{\text { foliage fall - cumulative }}$} & \multicolumn{2}{|c|}{ Dead trees - necromass } & \multirow{2}{*}{$\begin{array}{l}\text { Biomass and necromass } \\
\text { all tree components for } \\
\text { 9-year-observation }\end{array}$} \\
\hline & & woody parts & foliage & & woody parts - cumulative & foliage - cumulative & \\
\hline \multirow{2}{*}{ Beech } & absolute $\left[\mathrm{g} \mathrm{m}^{-2}\right]$ & 13,142 & 1,016 & 4,725 & 2,882 & 427 & 22,192 \\
\hline & relative [\%] & 59.2 & 4.6 & 21.3 & 13.0 & 1.9 & 100.0 \\
\hline \multirow{2}{*}{ Spruce } & absolute $\left[\mathrm{g} \mathrm{m}^{-2}\right]$ & 8,135 & 3,125 & 4,776 & 3,499 & 1471 & 21,007 \\
\hline & relative [\%] & 38.7 & 14.9 & 22.7 & 16.7 & 7.0 & 100.0 \\
\hline
\end{tabular}


decomposed faster than in spruce stand (needles). This statement is in accordance with the prevailing hypothesis that litter decomposition is faster in broadleaved stands than in coniferous ones (e.g. Berger \& Berger, 2014). The differences are often associated with dissimilar lignin and nutrient contentsof leaves and needles (Berger \& Berger 2014) and possibly with higher diversity of microbial decomposers in broadleaved than coniferous forests (He et al., 2007). As for woody debris, Shorohova \& Kapitsa (2016) commented that the decomposition rate in European forests depends on site moisture andon tree species. As for inter-specific differences, Hermann et al. (2015) found significantly higher decomposition rates of beech woody parts than those of spruce.

Concluding our results covering 9 years of observations in the young stands, the amount of biomass (fixed carbon) was only slightly larger than the overall cumulative necromass production (i.e. carbon transferred from biomass to necromass). Hence, a really large portion of carbon is allocated to necromass, from which it is subsequently emitted to the atmosphere. High tree mortality rate is a well-known phenomenon in dense young stands, and it is mostly related to the intensive competition for resources, mostly for light (e.g. Wright et al. 2000). Anyway, the total input to the necromass pool (annually $900 \mathrm{~g}$ per $\mathrm{m}^{2}$ and $1,100 \mathrm{~g}$ per $\mathrm{m}^{2}$ in the beech and spruce stand, respectively) can be relatively even larger than in old beech or spruce stand. Healthy old stand (especially if they were regularly thinned) is typical with very low tree mortality rate and the essential part of necromass input is usually represented by foliage fall. For instance, Pavlenda (2011) showed the annual foliage fall equaling about 320 g per $\mathrm{m}^{2}$ in a middle-age beech and slightly over $100 \mathrm{~g}$ per $\mathrm{m}^{2}$ in a middle-age spruce stand. Merganič et al. (2017) estimated about $250 \mathrm{~g}$ of foliage annually shed per $\mathrm{m}^{2}$ in the forests (prevailingly spruce) of the Czech Republic. Our previous studies (Barna et al. - unpublished data) in an old beech stand showed the annual foliage fall between 300 and $400 \mathrm{~g}$ per $\mathrm{m}^{2}$. The actual results in this paper indicate as much as $530 \mathrm{~g}$ per $\mathrm{m}^{2}$ of foliage fall per year estimated in both young beech and spruce stands.

It is generally known that young forests fix in their biomass much less carbon than old stands (see for instance Konôpka B. et al. 2016). However, they can represent (especially those from natural regeneration - usually very dense ones) considerable carbon flux to necromass. In the case of litter fall, the flux it may make up even larger amount than in old forests (compare our results with Merganič et al. 2017). Analogously, young stands should not be omitted in forest carbon balance estimates at regional, country or any other levels.

\section{Acknowledgement}

The study was supported by APVV-0273-11, APVV-0584-12, and $A P V V$-14-0086 projects financed by the Slovak Research and Development Agency. It was partly supported by the project QJ 1220316 from the Ministry of Agriculture of the Czech Republic.

\section{References}

Berger, T. W., Berger, P., 2014. Does mixing of beech (Fagus sylvatica) and spruce (Picea abies) litter hasten decomposition? Plant and Soil, 377:217-23.

He, X.-B., Song, F.-Q., Zhang, P., Lin, Y.-H., Tian, X.-J., Ren. L.-L. et al., 2007: Variation in litter decomposition-temperature relationship between coniferous and broadleaf forests in Huangshan Mountain, China. Journal of Forestry Research, 18:291-297.

Helmisaari, H. S., Makkonen, K., Kellomäki, S., Valtonen, E., Mälkönen, E., 2002: Below- and aboveground biomass, production and nitrogen use in Scots pine stand in eastern Finland. Forest Ecology and Management, 165:317-326.

Herrmann, S., Kahl, T., Bauhus, J., 2015: Decomposition dynamics of coarse woody debris of three important central European tree species. Forest Ecosystems, 2:2-27.

Konôpka, B., 2017: Foliage and fine root litter: A comparative study in young, natural regenerated stands of European beech and Norway spruce. Austrian Journal of Forest Science, (in press).

Konôpka, B., Moravčík, M., Pajtík, J., Lukac, M., 2011: Biomass partitioning and growth efficiency in four naturally regenerated forest tree species. Basic and Applied Ecology, 11:234-243.

Konôpka, B., Pajtík, J., Šebeň, V., 2016: Zmena zásob uhlíka v biomase lesných poratsov vo Vysokých Tatrách v dôsledku velkoplošnej disturbancie. Zprávy lesnického výzkumu, 61:239-246.

Konôpka, B., Pajtík, J., Máliš, F., Šebeň, V., Mal'ová, M., 2017: Carbon stock in aboveground biomass of vegetation at the High Tatra Mts. twelve years after disturbance. Central European Forestry Journal, 63: DOI: $10.1515 /$ forj-2017-7.

Konôpka, J., Šebeň, V., Konôpka, B., 2016: Zastúpenie drevín v mladých lesných porastoch na Slovensku. Lesnícke štúdie, 63, Zvolen, NLC-LVÚ Zvolen, 66 p.

Kunca, A., Zúbrik, M., Galko, J., Vakula, J., Leotnovyč, R., Konôpka, B. et al., 2015: Salvage felling in the Slovak forests in the period 2004-2013. Lesnícky časopis - Forestry Journal, 61:188-195.

Larson, A. J., Lutz, J. A., Donato, D. C., Freund, J. A., Swanson, M. E., Lambers, J. H. et al., 2015: Spatial aspects of tree mortality strongly differ between young and old-growth forests. Ecology, 96:2855-2861.

Merganič, J., Merganičová, K., Konôpka, B., Marušák, R., 2017: Country and regional carbon stock in forest cover - estimates based on the Czech National Forest Inventory data. Central European Forestry Journal, (in press).

Ministry of Agriculture of the Slovak Republic, 2016: Report on Forestry in the Slovak Republic per year 2016. Ministry of Agriculture of the Slovak Republic, Bratislava, $76 \mathrm{p}$. 
Nikolov, Ch., Konôpka, B., Kajba, M., Galko, J., Kunca, A., Janský, L., 2014: Post-disaster forest management and bark beetle outbreak in Tatra National Park: Mountain Research and Development, 34:326-335.

Pajtík, J., Konôpka, B., Lukac, M., 2008: Biomass functions and expansion factors in young Norway spruce (Picea abies [L.] Karst) trees. Forest Ecology and Management, 256:1096-1103.

Pajtík, J., Konôpka, B., Lukac, M., 2011: Individual biomass factors for beech, oak, and pine in Slovakia: a comparative study in young naturally regenerated stands. Trees, 25:277-288.

Pajtík, J., Konôpka, B., Marušák, R., 2013: Aboveground net primary productivity in young stands of beech and spruce. Lesnícky časopis - Forestry Journal, 59:163-171.

Pavlenda, P., Pajtík, J., Priwitzer, T., Bošel'a, M., Capuliak, J., Durkovičová, J. et al., 2011: Monitoring lesov Slovenska. Projekt FUTMONT, ČMS LESY 2010. Zvolen, Národné lesnícke centrum - Lesnícky výskumný ústav Zvolen, 205 p.
Shorohova, E., Kapitsa, E., 2016: The decomposition rate of non-stem components of coarse woody debris (CWD) in European boreal forests mainly depends on site moisture and tree species. European Journal of Forest Research, 135:593-606.

Thomas, S. C., Martin, A. R., 2012: Carbon content of tree tissues: A synthesis. Forests, 3:332-352.

Wirth, C., Schumacher, J., Schulze, E. D., 2004: Generic biomass functions for Norway spruce in central Europe - a meta-analysis approach toward prediction and uncertainty estimation. Tree Physiology, 24:121-139.

Wright, E.E., Canham, C.D., Coates, K. D., 2000: Effects of suppression and release on sapling growth for 11 tree species of northern, interior British Columbia. Canadian Journal of Forest Research, 30:1571-1580.

Appendix 1. Parameters of alometric equations for individual tree components of beech stands (after Konôpka et al. 2011).

\begin{tabular}{|c|c|c|c|c|c|}
\hline Tree component & Equation & $\mathrm{b}_{0}$ & $b_{1}$ & $b_{2}$ & $\lambda$ \\
\hline Foliage & $\left.B=e^{\left(b-b b_{1}+D A B+b\right.}{ }_{2}+h\right) \cdot \lambda$ & -5.943 & 2.783 & 0.332 & 1.045 \\
\hline Branches & $B=e^{\left(b_{0}+b_{1}+D A B+b\right.} 2_{2}^{+h) \cdot \lambda}$ & -4.768 & 2.630 & 0.423 & 1.130 \\
\hline Stem & $\left.B=e^{\left(b-b b_{1}+D A B+b\right.}{ }_{2}+h\right) \cdot \lambda$ & -1.530 & 1.848 & 1.015 & 1.026 \\
\hline Roots & $B=e^{\left(b-b_{0}+b_{1}+D A B+b\right.} 2_{2}^{+h) \cdot \lambda}$ & -2.898 & 2.336 & 0.025 & 1.098 \\
\hline Whole tree & $\left.B=e^{\left(b_{0}+b_{1}+D A B+b\right.} 2_{2}+h\right) \lambda$ & -1.236 & 2.124 & 0.521 & 1.038 \\
\hline
\end{tabular}

Appendix 2. Parameters of alometric equations for individual tree components of spruce stands (after Pajtík et al. 2008).

\begin{tabular}{|c|c|c|c|c|c|}
\hline Tree component & Equation & $\mathrm{b}_{0}$ & $b_{1}$ & $b_{2}$ & $\lambda$ \\
\hline Foliage & $\left.B=e^{\left(b+b_{1}+D A B+b\right.} 2_{2}+h\right) \lambda$ & -2.487 & 2.282 & 0.036 & 1.082 \\
\hline Branches & $\left.B=e^{(b+b} \theta_{1}^{+D A B+b}{ }_{2}+h\right) \cdot \lambda$ & -2.553 & 2.171 & 0.313 & 1.089 \\
\hline Stem & $\left.B=e^{\left(b+b_{1}+D A B+b\right.}{ }_{2}+h\right) \cdot \lambda$ & -0.469 & 1.555 & 0.913 & 1.020 \\
\hline Roots & $\left.B=e^{\left(b+b_{1}+D A B+b\right.}{ }_{2}+h\right) \cdot \lambda$ & -2.869 & 2.254 & -0.142 & 1.045 \\
\hline Whole tree & $B=e^{\left(b_{0}+b_{1}+D A B+b_{2}+h\right) \cdot \lambda}$ & -0.579 & 2.039 & 0.297 & 1.030 \\
\hline
\end{tabular}

